\title{
Impact of Corporate Social Responsibility on the Performance of Manufacturing Firms in Nigeria.
}

\author{
John Azumah* \\ Management, Department of Business Administration, Nile University of Nigeria, Abuja \\ *Corresponding Author: John Azumah Management, Department of Business Administration, Nile \\ University of Nigeria, Abuja, Nigeria
}

\begin{abstract}
Manufacturing firms contribute to environmental pollution and social costs in Nigeria today. To pay back to society and also increase long-term performance and stakeholder trust, manufacturing firms undertake corporate social activities in communities they are located. This study examines the impact of Corporate Social Responsibility (CSR) on the performance of manufacturing firms in Nigeria. A casestudy of Ariaria shoe making and footwear company ltd, Abia State, Nigeria (2005-2006). An ordinary least square regression is applied to annual aggregate data to determine the type of relationship that exist between the dependent and independent variables. A simple linear regression model is used in this study. The dependent variable is the performance indicator while the independent variable is: corporate social responsibility expenditure (ECSR). The financial performance indicators include: Profit after tax (PAT), Asset Financial Value (AFV) and Return on Investment (ROI), while the non-financial performance indicators are; Average Manufacturing Capacity Utilisation (AMCU), Employee's Productivity rate (EMR) and Company's output rate (COR).The technique used in estimating the parameters of the specified model is the Ordinary Least Squares (OLS) estimation method. The results of this study show that Corporate Social Responsibility Expenditure (ECSR) has a positive and significant impact on the Financial and non-financial Performance of Manufacturing Firms. A number of recommendations are made based on the research questions, research objectives and research findings prominent among them is the need for increased spending on CSR to improve the symbiotic sustainable relationship between CSR activities and firms' performance.
\end{abstract}

Key words: Corporate Social Responsibility, Manufacturing, Firms, Abuja and Nigeria

\section{INTRODUCTION}

\subsection{Background of the Study}

Corporate social responsibility (CSR) has become a global issue today and has been adopted by companies to help them face pressure from stakeholders and increase their competitive advantage and superior performance (Jenkins 2009, Torugsa et al. 2012). Several studies have shown different findings in analysing the relationship between CSR and firm performance.

Babalola (2012), Mishra and Suar (2010), Teimouri et al. (2011) revealed a positive relationship between CSR and firm performance. Here CSR activities involved external perception on the firm. Surroca et al. (2010) and Maduenoa et al. (2015) also indicated that maximizing the firm's intangible resources as a mediating factor will improve CSR influence on the firm's performance. Olowokudejo et al. (2011) Olusanya et al. (2012), and Okwemba et al. (2014) on the other hand, emphasized that there is no relationship between CSR and firm's performance. Maduenoa et al. (op.cit) stated that CSR indicates a very close reciprocal relationship between firm and stakeholders. Therefore, the relationship of CSR can be mediated by relationship capacity to improve the firm performance. The relational capacity can be done through active involvement of a community in CSR programs of firm's activities and hence, be beneficial to the community. The CSR practice of manufacturing industries focusing on environmental issues in order to reduce negative effects of the firm's activities and hence be beneficial to the community. The CSR practice of manufacturing industries focusing on environmental issues need the involvement of environmental management (Post et al. 2011). For a manufacturing firm whose activities require the involvement of wider community, whether as 
provider of raw materials, labour, and target markets, CSR is needed as an ethical and moral obligation of firm.

According to Awan Akhtar (2014) the history of CSR has been in the literature books for some decades. Some scholars have noted that CSR has been present in the management and accounting literature for about forty-five years in the developed world due to the level and consequences of industrial activities even though many corporate organisations' attention to its requirement has been relatively low until recently. In the case of the developing world, especially in Nigeria, the issue of CSR appears to be recent. This is evidenced by scanty literature in this area locally and the assertion by Osisioma, Nzewi and Nwoye (2015) that organisations operating in Nigeria have not done enough to improve the social welfare of the host communities where they are operating despite the huge amounts they realise. The day to day activities of manufacturing firms in Nigeria are largely associated with all kinds of negative impact on the firm's environment such as pollution of all sorts (noise, air, water, as well as environmental damage and disruption), social vices such as armed robberies, kidnappings, etc. CSR strategy needs to be directed to ethical issues of the environment so as to reduce the negative impact of firms' activities, improve profitability, financial gain, and competitiveness and at the same time benefit society (King and Lenox 2002, Klassen and Whybark 1991, Orlitzky et al. 2011).

The bottom line is that the issues of CSR have gained universal attention in view of the globalisation of all facets of business notably in the financial reporting system of corporate organisations. It has become the main issues of discourse in view of several agitations and expression of anger by host communities in Nigeria against the backdrop of the seeming neglect of the adverse impact of their operations on the environment by corporate entities (the case of the Niger Delta militants in Nigeria).Significant improvement in the legal framework and political structure of the country have increased the level of awareness of communities. Thus, citizens are increasingly demanding corporations to justify and legitimise not only their economic actions but also their social and environmental concerns.

The literature has revealed two approaches to evaluating the likely impact of CSR on firms' performance. First, the focus is on how CSR affects the shareholder's net earnings while the second approach focuses on other interest groups rather than the shareholders. An approach that focuses on the owners' earnings tend to leave the impression that adherence to the tenets of CSR has a negative impact on the firm's performance (measured by profitability), as undertaking the obligations associated with CSR would necessarily add to the cost of operations of the firm which threatens their reported profits. However, a focus on the welfare and satisfaction of other interest groups would tend to have a positive impact on the firm's performance (when performance is measured in terms of market value) particularly in the long run. Thus, paying attention to the interest groups would create value for the firm from the public perspective.

Servaes and Tamayo (2012) observe that while there appears to be more support for the view that CSR activities are positively related to profitability and firm value, a good number of studies find the opposite relationship and the research on CSR impact on firms' performance are still uncertain. This study therefore seeks to evaluate the impact that CSR activities has on manufacturing firms' performance in Nigeria. This study will use the shoe and footwear sector as a case.

\subsection{Statement of Research Problem}

In today's competitive world, the rating of firms 'performance by the various interest groups has incorporated other indicators other than only profitability measures. One of such other considerations is how responsible a firm is in terms of its corporate social obligations. Here, the firm is expected to be a corporate social citizen.

From the capitalism point of view, a firm's performance is seen in terms of profit maximisation. Strategically, firms try to minimise costs in their operations at the same time maximising profits. As a result, adherence to CSR requirements threatens the profit maximization goal (at least in the shortrun) as its cost implications increase the overall cost of operation of the firm while also reducing the distributable profit to the owners. Here, it could be said that undertaking CSR programmes negatively affect the profit performance of firms. However, from a competitive strategy angle, the interest of other stakeholders must be incorporated in evaluating the firm's performance. Here, the performance 
is seen in terms of contributions to the firm's market value rather than just profitability. Thus, Afsheen (2015) asserts that the products of those companies that are performing CSR activities are preferred by people. Where a firm has not respected its social obligations especially in respect of the environment, it has always resulted in violent agitations by communities in which firms operate in the form of social vices such as Kidnappings, vandalism, armed robbery as a way of pressing home their demands. These negative actions create unhealthy and non-peaceful atmosphere for the companies and sometimes results in shutdown of operations which adversely affect firm's performance.

On the one hand, most previous studies in this area have been foreign dominated. On the other, we have scanty literature locally on the subject of CSR. While most of the foreign studies have found a positive significant relationship between CSR and firms' performance, some studies in some instances found no significant relationship, indicating mixed results from previous studies. As a result, Servaes and Tamayo (op.cit) assert that while there appears to be more support for the view that CSR activities are positively related to profitability and firm value, a large number of studies find opposite relationship thereby rendering the impact of research of CSR activities on firms' performance still uncertain.

\subsection{Objective of the Study}

This study mainly targets to ascertain the impact on firms 'performance of CSR activities undertaken by manufacturing firms in Nigeria.

Consequently, the study specifically seeks to:

- Evaluate the relationship between CSR expenditure and profit after tax (PAT) of manufacturing firms in Nigeria

- Determine the implications of CSR cost on Return on Investment (ROI) of manufacturing firms in Nigeria

- Assess the impact of CSR expenditure on Asset Financial Value (AFV) of manufacturing firms in Nigeria

\subsection{Research Questions}

- Does CSR expenditure have any positive and significant relationship on PAT of manufacturing firms in Nigeria?

- What are the implications of CSR spending on the ROI of manufacturing firms in Nigeria?

- What is the impact of CSR spending on AFV of the manufacturing firms in Nigeria?

\subsection{Research Hypotheses}

Ho1 There is no positive and significant relationship between CSR expenditure and PAT of manufacturing firms in Nigeria.

Ho2 CSR spending has no significant implications on ROI of manufacturing firms in Nigeria.

Ho3 Expenditure on CSR by manufacturing firms in Nigeria has no significant effect on the firms' AFV.

\section{LITERATURE REVIEW}

\subsection{Concept of Corporate Social Responsibility (CSR)}

Arguments for and against CSR have persisted over the years. It is anchored on whether business is seen primarily as an economic system responsible only to satisfy their owners or a socio-economic system responsible to various interest groups such as employees, consumers, community and environment Okeudo, (2012). CSR as a concept has no consensus definition. Various scholars' definition is based on their background, interest, exposure as well as values embodied in their frame of reference. CSR is also called corporate conscience or corporate social performance and based on the duties performed by organizations to the society in which they operate such as, protection of the environment, provision of social amenities, donations to health organisations, charitable contributions to approved organisations and so on, Odetayo and Adeyemi (2017). Black (2009) classifies CSR into four categories which are; Enterprise (Supporting and developing initiatives to nurture budding enterprises and boost enterprise), Education (Helping to bring new horizons into the lives of young 
people), Arts and Culture (Providing assistance to a range of artistic activities and bringing communities together) and Environment (encouraging efforts to safeguard the environment and improve the quality of life). Onabanjo (2015) provides what he calls a partial list of CSR categories which includes being responsible for; product lines, marketing practices, employee service, corporate philanthropy, environmental activities and employee safety and health. CSR as posited by Olaroyeke and Nasieku (2015) encompasses a variety of issues revolving around companies' interactions with society. It refers to sets of actions that appear to further some social good, beyond the interests of the firm and that which is required by law (McWilliams \& Siegel, 2018). As such it involves a wide range of activities such as being employee-friendly, environment-friendly, and respectful of communities where the firms' plants are located, and even investor-friendly (Bénabou \& Tirole, 2017). According to Enahoro, Akinyomi, \& Olutoye, (2018), CSR covers a wide range of issues such as plant closures, employee relations, human rights, corporate ethics, community relations and the environment.

In essence, CSR may be described as an approach to decision making which encompasses both social and environmental factors. It can therefore be inferred that CSR is a deliberate inclusion of public interest into corporate decisions making and the honouring of a triple bottom line which are People, Planet and Profit (Harpreet, (op cit). The triple bottom line is considering that companies do not only have one objective; profitability, but that they also have objectives of adding environmental and social value to society (Mirfazli, 2018).

Given the globalisation trend in all spheres of business organisations, attention of corporate entities are necessarily shifted from solely owners' interests and the satisfaction of customer needs to include other relevant stakeholders that can affect or are affected by companies' activities. Odetayo, Adeyemi and Sajuyigbe (op cit) holistically described CSR as the organisation responding positively to emerging societal priorities and expectations, conducting business in an ethical way and in the interests of other stakeholders in the society. In fact, the idea of CSR implies how organizations can manage its business process to produce an overall positive impact on economic development of society. It also means how organizations behave ethically and contribute to economic development of the society by improving the quality of life of the local community and society at large.

\subsubsection{Concept of Firm Performance}

A wide variety of definitions of firm performance have been proposed in the literature. Both accounting and market definitions have been used to study the relationship between CSR and firm performance (Orlitzky et al, (op cit). Performance measurement refers to the process of measuring the actions of firms 'efficiency and effectiveness (Al Matari, Al Swidi and Fadzil 2014). The most common measure of performance in firms is the financial performance measurement although such other measure like output and capacity utilization could be employed as measures of performance particularly in manufacturing outfits. According to Malik and Nadeem (2014), financial performance can be defined as measures that evaluate the financial position of a company over a specified time period to know how efficiently is using its resources to generate income. Return on Investment, Return on Equity, Net Profit, Earning per share, Asset financial Value, etc are evaluated to measure firm's financial health. Neely (2007) highlighted three different major functions for the use of financial performance measures as follows:

1. The use of financial measures of performance as a tool of financial management. Here, the focus is on functional specialism of finance and financial management. This is concerned with the efficient provision and use of financial resources to support the wider aims of the organisation, and to manage the effective operation of the finance function.

2. The role of financial performance as major objective of a business organization. Here, some overarching financial performance measure such as profit, return on investment (ROI), is used to signify the achievement of an important (perhaps the most important) organisation objective.

3. The function of financial performance measures as a mechanism for motivation and control within the organisation. Here, the financial information provides a "window" into the organisation by which specific operations are managed through the codification of their input in financial terms.

Malik and Nadeem highlighted the following measures of financial performance of firms:

- Earnings per share (EPS): EPS show the earning of firms that is how much profit is earned during the period of one year on behalf of each outstanding share of common stock. 
- Return on Assets (ROA): ROA often called the return on investment (ROI). ROA show the profit generated by the asset of the firms annually. ROA is an indicator that show how much an organization is earning over its total assets.

- Return on Equity (ROE): ROE measures the return earned on both preferred and common stockholders' investment in financial institution annually. It shows the ability of generating profits from every unit of shareholders equity.

- Net Profit: Net profit means revenues minus all expenses. Net profit of the organization is shown after deducting the interest expense and tax on the profit.

- Asset Financial Value: The monetary value of a given investment in an organisation.

More elaborately, Al-Matari, Al-Swidi and Fadzil enumerated the following as measures of a firms financial performance: Return on Asset (ROA), Return on Equity (ROE), Tobin-Q, Profit Margin (PM), Asset Financial Value (AFV), Earning Per Share (EPS), Dividend Yield (DY), Price Earning Ration (PE), Return on Sales (ROS), Expense To Asset (ETA), Cash To Asset (CTA), Sales To Asset (STA), Expense To Sales (ETS), Abnormal Returns, Annual Stock Return, Operating Cash Flow (OCF), Return on Capital Employed (ROCE), Labour Productivity (LP), Critical Business Return To Asset (CROA), Cost of Capital (COT), Market Value Added (MVA), Operating Profit (OP), Return on Investment (ROI), Market To Book Value (MTBV), Growth In Sales (GRO), Log of Market Capitalization, Stock Repurchases, Sale Per Employee (SPE), Return on Revenue (ROR), Output Per Staff (OPS), Cost Per Service Provided (CPSP), Cost Per Client Served (CCS), Superior To Cumulative Abnormal Returns (CARs), Profit Per Employee (PPE), Return on Fixed Asset (ROFA), etc. They opined that accounting-based measurement is generally considered as an effective indicator of the company's profitability. The accounting-based measurement indicators of the profitability of firms could be calculated (as articulated by Al-Matari, Al-Swidi and Fadzil), as follows:

Table1. Calculating of Profitability Measures

\begin{tabular}{|l|l|}
\hline Measures & How to Calculate \\
\hline Return on Asset (ROA) & Net Income over total asset at the end of the year \\
\hline Return on Equity (ROE) & Profit after tax over total equity shares in issue \\
\hline Return on Sales (ROS) & Sales over net profit \\
\hline Return on Investment (ROI) & Total investment cost over return on investment \\
\hline Profit Margin (PM) & Profit after tax over turnover \\
\hline Operating Cash Flow (OCF) & Net Income before depreciation expense over total assets \\
\hline Earnings Per Share (EPS) & Net income over total shares \\
\hline Operating Profit (OP) & Operating income before depreciation value of total assets \\
\hline Growth In sales (GRO) & $\begin{array}{l}\text { Calculated by dividing the difference between current year's sales } \\
\text { volume }\end{array}$ \\
\hline $\begin{array}{l}\text { Return on Capital Employed } \\
\text { (ROCE) }\end{array}$ & Profit before tax over issued capital \\
\hline Expense To Asset (ETA) & Total expense over total assets. \\
\hline Cash To Asset (CTA) & Cash over total assets \\
\hline Sales To Asset (STA) & Total sales over total assets \\
\hline Expense to Sales (ETS) & Total expense over total sales \\
\hline
\end{tabular}

Source: Al-Matari, Al-Swidi and Fadzil (2014)

\section{$>$ Impact of CSR Strategy on manufacturing firms}

Scholars have highlighted some benefits to CSR strategy of manufacturing firms. The result of a survey by Okeudo (op.cit) indicates that a greater percentage of companies believe the development of a CSR strategy can deliver real business benefits. However, only a few have made significant progress in complimenting the strategy in their organizations. The survey concluded that CEOs are failing to recognize the benefits of implementing social responsibility strategy despite increased pressure to include ethical, social and environmental issues into their decision-making process. Thus Okeudo(op cit) asserts that organizations should conduct business ethically and demonstrate leadership in satisfying their responsibility to the society; they should aim to support and encourage their employees and to demonstrate to the community that a business is committed to improving its environment. Therefore, businesses would embrace responsibility for the impact of their activities on the environment, consumers, employees, community, stakeholders and all other members of the 
public sphereOkeudo (op.cit). According to Kotler and Lee (2005), Grigore and Rosca 2011 the studies regarding the benefits of CSR points out the following aspects: increased sales and market share, strengthens brand positioning, enhances corporate image and clout, increases the ability to attract employees, decreases operating cost and increases appeal to investors. Miles and Munilla 2005, Malikand Nadeem (op.cit) described the motives for participating in CSR by using Caroll's (1991) pyramid of CSR which illustrates how different levels of commitments are related to motives and outcome. A company's CSR philosophy can be compliance driven, profit driven, driven by caring, synergetic or holistic. In the first stage of CSR category, which is called the legal stage, companies engage in CSR as it is their duty and obligation to follow laws and regulations. In the economic stage, companies use CSR as a strategy to create a competitive advantage and gain improved financial performance. The ethical and philosophical stage has the aim to have a balance between the profit, people and the planet. In this stage the company does not only focus on profit but also on social welfare Malikand Nadeem (op cit)

Idowu and Papasolomou (2017) observe that several authors argue that companies can gain enormous benefits by being socially responsible. Hence, a large number of different views of why companies engage in CSR and what benefits a company actually gets from participating in CSR exist. Companies participate in CSR in order to look better, feel better, do better and live longer. The authors further explain that by participating in CSR the company will look good in the view of potential customers, businesses, colleagues, investors and in the media, etc. Furthermore, employees, customers, stockholders and board members will actually feel good. Many researchers also argue that CSR improves the brand, and some claim that companies with a strong reputation for CSR will last longer. Brammer, Pavelin and Porter (2006) opined that the reasons for participating in CSR include moral obligation, sustainability, license to operate and reputation.

Okeudo (op.cit) identified the following as the key drivers of CSR:

- Enlightenment self-interest- creating synergy of ethics, a cohesive society and a sustainable global economy where markets, labour and communities are able to function well together.

- Social investment- contributing to physical infrastructure and social capital is increasingly seen as a necessary part of doing business.

- Transparency and trust- business has two ratings of trust in public perception. There is increasing expectation that companies will be more open, more accountable and be prepared to report publicly on their performance in social and environmental arenas.

- Increased public expectations of business- global companies are expected to do more than merely provide jobs and contribute to the economy through taxes and employment. On the other hand, Malik and Nadeem (op.cit) highlight that education, health and donation are the determinants of CSR.

\subsection{Theoretical Framework}

This study adopts the stakeholder theory and is a system-oriented theory which assumes that any organisation is influenced by the society in which it operates and, in turn, the organisation also influences society. In this study, companies are considered to engage in some form of stakeholder management. Firm's survival and success is attributable to economic and non-economic achievements. Being socially responsible and having good relations with their stakeholders will bring about competitive advantage, making them to achieve better economic results (e.g. profit maximization) and non-economic (e.g. corporate social performance) results. The stakeholder theory argues that a firm's financial success is dependent on its ability to formulate and execute a corporate strategy which manages its relationships with stakeholders effectively (Brammer, Pavelin, \& Porter op cit)

\subsection{Empirical Review}

It is important for this research work to examine some of the empirical studies that have been carried out in this field of study. Many studies have been carried out on corporate social responsibility, among them are some empirical studies as shown in the table below:

\begin{tabular}{|l|l|l|l|}
\hline Author(s) \&date & Topic Studied & $\begin{array}{l}\text { Sample and Methods } \\
\text { Employed }\end{array}$ & Major Findings \\
\hline $\begin{array}{l}\text { Javed, Saeed, Lodhi } \\
\text { and Malik (2013) }\end{array}$ & $\begin{array}{l}\text { The relationship } \\
\text { between }\end{array}$ firms' & $\begin{array}{l}\text { The study used Carroll } \\
\text { Model of CSR on KSE }\end{array}$ & $\begin{array}{l}\text { There is a positive relationship } \\
\text { between firms; financial }\end{array}$ \\
\hline
\end{tabular}




\begin{tabular}{|c|c|c|c|}
\hline & $\begin{array}{lr}\text { financial performance, } \\
\text { economic and legal } \\
\text { responsibilities and } \\
\text { ethical and } \\
\text { discretionary } \\
\text { responsibilities }\end{array}$ & $\begin{array}{l}30 \text { index companies of } \\
\text { Pakistan }\end{array}$ & $\begin{array}{l}\text { performance, economic and legal } \\
\text { responsibilities. However, there } \\
\text { is a negative relationship between } \\
\text { the cases of legal discretionary } \\
\text { responsibilities. They also } \\
\text { conclude that CSR by corporate } \\
\text { sector provides a healthy } \\
\text { environment for the country and } \\
\text { promotes a culture in which laws } \\
\text { are abided willingly. }\end{array}$ \\
\hline $\begin{array}{ll}\text { Kanwal and } \\
\text { Hameed (2018) }\end{array}$ & $\begin{array}{l}\text { CSR and firms' } \\
\text { performance }\end{array}$ & $\begin{array}{l}\text { Kenya Stock Exchange } \\
\text { (KSE) different listed } \\
\text { companies of Pakistan }\end{array}$ & $\begin{array}{l}\text { CSR activities give dual benefits. } \\
\text { On the one hand they enhance a } \\
\text { positive image in the minds of } \\
\text { their stakeholders. On the other, } \\
\text { they improve the financial } \\
\text { position. }\end{array}$ \\
\hline Cheruiyot (2018) & $\begin{array}{l}\text { CSR and financial } \\
\text { performance of firms } \\
\text { listed on Kenya Stock } \\
\text { Exchange in terms } \\
\text { ROA,ROE and ROS }\end{array}$ & $\begin{array}{l}\text { This was a cross } \\
\text { sectional study of } 47 \\
\text { listed companies in the } \\
\text { Nigerian as Stock } \\
\text { Exchange as at } \\
\text { December 2018 using } \\
\text { regression analysis }\end{array}$ & $\begin{array}{l}\text { There was a statistically } \\
\text { significant relationship between } \\
\text { CSR and financial performance. }\end{array}$ \\
\hline $\begin{array}{l}\text { Uwaloma and } \\
\text { Fagbemi (2018) }\end{array}$ & $\begin{array}{l}\text { CSR and financial } \\
\text { leverage of } \\
\text { manufacturing firms }\end{array}$ & $\begin{array}{l}\text { Research on } 41 \text { listed } \\
\text { companies on Nigerian } \\
\text { Stock Exchange } 2017 \\
\text { using multiple } \\
\text { regression analysis }\end{array}$ & $\begin{array}{l}\text { The study revealed that a } \\
\text { significant negative relationship } \\
\text { between manufacturing firms } \\
\text { 'financial leverage and level of } \\
\text { CSR disclosures. }\end{array}$ \\
\hline Scholtens (2018) & $\begin{array}{l}\text { Relationship between } \\
\text { CSR and financial } \\
\text { performance of } \\
\text { manufacturing firms in } \\
\text { the US for the period } \\
\text { of 1991-2015 }\end{array}$ & $\begin{array}{l}\text { Investigated a sample } \\
\text { of } 289 \text { firms using } \\
\text { ordinary least square } \\
\text { (OLS) and Granger } \\
\text { causation techniques of } \\
\text { analysis. }\end{array}$ & $\begin{array}{l}\text { Concluded that there was } \\
\text { significant correlation between } \\
\text { CSR and financial performance, } \\
\text { although components of CSR } \\
\text { such a community involvement, } \\
\text { employee relations, diversity, } \\
\text { environment, did not have } \\
\text { positive relationship in respect of } \\
\text { risk and return }\end{array}$ \\
\hline $\begin{array}{l}\text { Foote, Gaffney, and } \\
\text { Evans (2015) }\end{array}$ & $\begin{array}{l}\text { CSR on performance } \\
\text { of Manufacturing } \\
\text { organisations }\end{array}$ & $\begin{array}{l}\text { Used Malcolm } \\
\text { Baldrige criteria to } \\
\text { study various theories } \\
\text { of firms' management } \\
\text { and current academic } \\
\text { thought }\end{array}$ & $\begin{array}{l}\text { They conclude that there was no } \\
\text { positive influence of CSR on } \\
\text { firms' performance }\end{array}$ \\
\hline Afsheen (2015) & $\begin{array}{l}\text { Impact of CSR on } \\
\text { firms' performance }\end{array}$ & $\begin{array}{l}\text { Studied sample of } 101 \\
\text { staff in Pakistan using } \\
\text { correlation } \quad \text { and } \\
\text { regression analysis } \\
\text { techniques }\end{array}$ & $\begin{array}{l}\text { The study found CSR strongly } \\
\text { impacted on firms' performance } \\
\text { and that it performed activities } \\
\text { contributing to enhancing } \\
\text { profitability increasing market } \\
\text { worth, value and stakeholder } \\
\text { interest of firms }\end{array}$ \\
\hline $\begin{array}{l}\text { Awan \& Akhtar } \\
(2014)\end{array}$ & $\begin{array}{l}\text { Impact of CSR on } \\
\text { profitability of firms: a } \\
\text { case study of fertilizer } \\
\text { and cement industry in } \\
\text { Southern Punjab, } \\
\text { Pakistan }\end{array}$ & $\begin{array}{l}\text { Fertilizer and cement } \\
\text { industries were used as } \\
\text { samples. Delphi and } \\
\text { OLS regression } \\
\text { method were used. }\end{array}$ & $\begin{array}{l}\text { Findings showed that the } \\
\text { relationship between CSR and } \\
\text { human rights, environment, } \\
\text { labour standard, corporate } \\
\text { governance and organisation's } \\
\text { interest were positive and } \\
\text { significant }\end{array}$ \\
\hline $\begin{array}{l}\text { Chetty, Naidoo and } \\
\text { Seetharam (2015) }\end{array}$ & $\begin{array}{l}\text { Impact of CSR on } \\
\text { firms' performance in } \\
\text { South Africa }\end{array}$ & $\begin{array}{l}\text { Regression analysis } \\
\text { was used covering the } \\
\text { period 2004-2013 }\end{array}$ & $\begin{array}{l}\text { Study found that CSR activities } \\
\text { led to no significant difference in } \\
\text { financial performance }\end{array}$ \\
\hline Jaenik (2013) & $\begin{array}{l}\text { Analysis of how CSR } \\
\text { policies create Value }\end{array}$ & $\begin{array}{l}\text { Cross sectional survey } \\
\text { design and non- }\end{array}$ & $\begin{array}{l}\text { It found that CSR improves } \\
\text { organisational performance by }\end{array}$ \\
\hline
\end{tabular}




\begin{tabular}{|c|c|c|c|}
\hline & added for companies & $\begin{array}{l}\text { probability sample } \\
\text { method were used. } \\
\text { Descriptive statistics } \\
\text { (tables, bar charts, pie } \\
\text { charts,) and the } \\
\text { economic Value } \\
\text { Added (EVA) concept } \\
\text { by Stern Stewart \& Co. } \\
\text { were used in the } \\
\text { analysis. }\end{array}$ & $\begin{array}{l}\text { enhancing the positive reputation } \\
\text { of the organisation with all } \\
\text { stakeholders and absolute value } \\
\text { added within the company. }\end{array}$ \\
\hline $\begin{array}{l}\text { Malik and Nadeem } \\
(2014)\end{array}$ & $\begin{array}{l}\text { Impact of CSR on the } \\
\text { financial performance } \\
\text { of banks in Pakistan }\end{array}$ & $\begin{array}{l}\text { The study used } \\
\text { regression analysis on } \\
\text { data collected for the } \\
\text { period 2008-2012 }\end{array}$ & $\begin{array}{l}\text { Findings showed that there is a } \\
\text { positive relationship between } \\
\text { profitability (EPS, ROA, ROE, } \\
\text { Net Profit) and CSR practices; } \\
\text { and that the financial institutions } \\
\text { that implement CSR in their } \\
\text { operations earn more profit for } \\
\text { the long term periods }\end{array}$ \\
\hline $\begin{array}{ll}\text { Mujahid } & \& \\
\text { Abdullah (2014) } & \end{array}$ & $\begin{array}{l}\text { Impact of CSR on } \\
\text { firms' } \\
\text { performancerinancial } \\
\text { shareholders' wealth }\end{array}$ & $\begin{array}{l}10 \text { highly rated firms } \\
\text { on CSR and } 10 \text { non- } \\
\text { CSR firms were } \\
\text { sampled. Simple } \\
\text { percentage and ratio } \\
\text { analysis were used. }\end{array}$ & $\begin{array}{l}\text { The result showed a significant } \\
\text { positive relationship between } \\
\text { CSR and firms' financial } \\
\text { performance and shareholders' } \\
\text { wealth }\end{array}$ \\
\hline $\begin{array}{l}\text { Odetayo, Adeyemi } \\
\text { \& Sajuyigbe (2014) }\end{array}$ & $\begin{array}{ll}\text { Impact of CSR } & \text { on } \\
\text { profitability } & \text { of } \\
\text { Nigerian banks } & \end{array}$ & $\begin{array}{lr}\text { The study sampled six } \\
\text { banks for the period of } \\
10 \text { years } & (2003-2012) \text {. } \\
\text { Sample regression } \\
\text { analysis r } \\
\text { employed. }\end{array}$ & $\begin{array}{l}\text { The regression results revealed } \\
\text { that there is a significant } \\
\text { relationship between expenditure } \\
\text { on CSR and profitability of } \\
\text { Nigerian banks. }\end{array}$ \\
\hline Okeudo (2012) & $\begin{array}{l}\text { Effects of CSR on the } \\
\text { society (using Shell } \\
\text { Petroleum } \\
\text { Development } \\
\text { Company (SPDC) of } \\
\text { Nigeria ltd as a case } \\
\text { study) }\end{array}$ & $\begin{array}{l}\text { The study utilized data } \\
\text { from } 86 \text { respondents } \\
\text { while using tables and } \\
\text { simple percentages for } \\
\text { the analysis. It } \\
\text { employed chi-square } \\
\text { for the statistical tests. }\end{array}$ & $\begin{array}{l}\text { The study found that benefits } \\
\text { accrue to stakeholders as a results } \\
\text { of the social commitments of } \\
\text { SPDC indicating a case of } \\
\text { significant positive effect of CSR } \\
\text { practice by shell on the society. }\end{array}$ \\
\hline $\begin{array}{l}\text { Servaes \& Tamayo } \\
(2012)\end{array}$ & $\begin{array}{l}\text { Impact of CSR on firm } \\
\text { value: The role of } \\
\text { Customer Awareness }\end{array}$ & $\begin{array}{l}\text { The study employed } \\
\text { OLS regression in its } \\
\text { analysis }\end{array}$ & $\begin{array}{l}\text { The findings were that CSR and } \\
\text { firm value are positively related } \\
\text { for firms with high customer } \\
\text { awareness. However, for firms } \\
\text { with low customer awareness the } \\
\text { relation is either negative or } \\
\text { insignificant. }\end{array}$ \\
\hline Babalola (2012) & $\begin{array}{l}\text { Impact of CSR on } \\
\text { firms' profitability in } \\
\text { Nigeria }\end{array}$ & $\begin{array}{l}10 \text { randomly selected } \\
\text { firms annual reports } \\
\text { and financial summary } \\
\text { between 1999-2008 } \\
\text { were studied OLS } \\
\text { regression analysis }\end{array}$ & $\begin{array}{l}\text { The results showed negative } \\
\text { relationship exists between firm's } \\
\text { performance measures with profit } \\
\text { after tax investment in social } \\
\text { responsibility which implies that } \\
\text { the more the profit recorded by } \\
\text { firms in Nigeria the less they } \\
\text { invest in CSR responsibilities. } \\
\text { This suggests that these } \\
\text { organisations' survival and } \\
\text { ability to make profit in the long } \\
\text { run could be threaten as various } \\
\text { stakeholders particularly the host } \\
\text { communities could threaten their } \\
\text { existence. }\end{array}$ \\
\hline $\begin{array}{l}\text { Amole, Adebiyi \& } \\
\text { Awolaja (2012) }\end{array}$ & $\begin{array}{l}\text { CSR and profitability } \\
\text { of Nigerian Banks: A } \\
\text { causal relationship }\end{array}$ & $\begin{array}{l}\text { This study used the } \\
\text { annual report of First } \\
\text { Bank of Nigeria plc for }\end{array}$ & $\begin{array}{l}\text { The finding were that there is } \\
\text { positive relationship between } \\
\text { banks and CSR activities and }\end{array}$ \\
\hline
\end{tabular}




\begin{tabular}{|c|c|c|c|}
\hline & & $\begin{array}{l}\text { the period 2001-2010. } \\
\text { Correlation and } \\
\text { regression analysis was } \\
\text { used in analysing the } \\
\text { data. }\end{array}$ & profitability. \\
\hline $\begin{array}{l}\text { Osisioma, Nzewi } \\
\text { and Nwoye (2015) }\end{array}$ & $\begin{array}{l}\text { CSR and performance } \\
\text { of selected firms in } \\
\text { Nigeria }\end{array}$ & $\begin{array}{l}\text { The study was on } 10 \\
\text { listed firms on the } \\
\text { Nigeria Stock } \\
\text { Exchange (NSE) for } \\
\text { the period } \\
\text { between2007-2011 and } \\
\text { applied the Pearson's } \\
\text { Product Moment } \\
\text { correlation. }\end{array}$ & $\begin{array}{l}\text { The study found that there is a } \\
\text { strong significant positive } \\
\text { relationship existing between } \\
\text { social responsibility cost and } \\
\text { corporate profitability. }\end{array}$ \\
\hline
\end{tabular}

Source: A summary of Empirical Review

\section{METHODOLOGY}

The study examines the impact of corporate social responsibility (CSR) on the performance of manufacturing firms in Nigeria; a case study of Ariaria Shoe making and footwear company Aba, Abia State Nigeria (2005-2018). The design is ex-post facto research design. It makes use of data collected from central bank of Nigeria and Manufacturers Association of Nigeria (MAN) report. A Simple linear regression analysis is conducted to examine the data obtained on corporate social responsibility (CSR) whose proxy is corporate social responsibility expenditure (ECSR). This study also examined the financial and non financial performance of the manufacturing firm. The financial performance indicators include: Profit after tax (PAT), Asset Financial Value (AFV) and Return on Investment (ROI), while the non financial performance indicators are; Average Manufacturing Capacity Utilisation (AMCU), Employee's Productivity rate (EMR) and Company's output rate (COR).The technique used in estimating the parameters of the specified model is the Ordinary Least Squares (OLS) estimation method. The justification for choosing the OLS as the estimation technique was due to the desirable properties its estimate possess called the BLUE properties. These properties ensure good inference making, and efficient as well as non-misleading conclusion and recommendations. The OLS estimation of the specified model was done using Econometric Views (Eviews) software. The dependent variable is the performance indicator while the independent variable is: corporate social responsibility expenditure (ECSR).

The data were analyzed using a multiple linear regression model of the form:

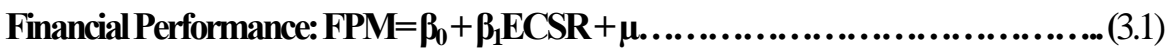

Where:

FPM = Financial Performance of Manufacturing Firm (shoe and footwear industry)

ECSR $=$ Corporate Social Responsibility Expenditure

$\beta_{0}=$ Intercept

$\beta_{1}=$ Slope of the Linear regression model

$\mu=$ Stochastic error term.

The apriori expectations with respect to the variableand parameterin the model are as follows; $\beta_{1}>0$,

NONFinancial Performance: $\mathrm{NFPM}=\beta_{0}+\beta_{1} \mathrm{ECSR}+\mu$.

Where:

NFPM $=$ Non-Financial Performance of Manufacturing Firm (shoes and footwear industry)

ECSR $=$ Corporate Social Responsibility Expenditure

$\beta_{0}=$ Intercept

$\beta_{1}=$ Slopes of the Linear regression model

$\mu=$ Stochastic error term.

The apriori expectations with respect to the variableand parameterin the model are as follows; $\beta_{1}>0$, 


\section{RESULTS AND ANALYSIS}

\subsection{Descriptive Statistics}

Table 4.1.1 below shows the descriptive statistics on the financial performance of the manufacturing firm (shoes and footwear industry). It captures the number of observations $(\mathrm{N})$, minimum, maximum, mean, Median and standard deviation of the variables used. Expenditure by Corporate Social Responsibility (ECSR) has a Mean value of 20.72659, Median value of 16.20928 with a standard deviation value of 12.20928. It has a minimum and maximum value of 4.20999 and 50.20888 respectively. Profit after Tax (PAT) has a Mean and median values of 21.62857 and 19.70000 respectively; with a standard deviation value of 14.16238. It has a minimum and maximum value of 3.400000 and 67.30000 respectively. Return on investment (ROI) has a Mean and median values of 94.52857 and 101.8000 respectively; with a standard deviation value of 19.74127 . It has a minimum and maximum values of 45.30000 and 117.3000 respectively. Asset Financial value (AFV) has a Mean and median values of 101.5714 and 103.3500 respectively; with a standard deviation value of 12.17124. It has a minimum and maximum value of 78.60000 and 120.0000 respectively, with 14 as the total number of observation. The data used in this study is presented at the appendix.

Table4.1.1. Descriptive Statistics For Financial Performance indicator on Shoe and footwear Industry

\begin{tabular}{|l|l|l|l|l|}
\hline & ECSR & PAT & ROI & AFV \\
\hline Mean & 20.72659 & 21.62857 & 94.52857 & 101.5714 \\
\hline Median & 16.20928 & 19.70000 & 101.8000 & 103.3500 \\
\hline Maximum & 50.20888 & 67.30000 & 117.3000 & 120.0000 \\
\hline Minimum & 4.20999 & 3.400000 & 45.30000 & 78.60000 \\
\hline Std. Dev. & 12.20928 & 14.16238 & 19.74127 & 12.17124 \\
\hline Observations & 14 & 14 & 14 & 14 \\
\hline
\end{tabular}

Source: Author's Computation, May 2020

Table4.2.1. Descriptive Statistics For Non-Financial Performance indicator

\begin{tabular}{|l|l|l|l|l|}
\hline & ECSR & AMCU & EMR & COR \\
\hline Mean & 91.64615 & 74.38462 & 69.69231 & 68.76923 \\
\hline Median & 89.60000 & 76.00000 & 68.00000 & 67.00000 \\
\hline Maximum & 102.0000 & 99.00000 & 87.00000 & 88.00000 \\
\hline Minimum & 67.00000 & 56.00000 & 45.00000 & 45.00000 \\
\hline Std. Dev. & 10.26187 & 12.80975 & 10.88871 & 16.27449 \\
\hline Observations & 14 & 14 & 14 & 14 \\
\hline
\end{tabular}

Source: Author's Computation, May 2020

Table 4.2.1 above shows the descriptive statistics on the non financial performance of the manufacturing firm (shoe and footwear industry). It consist of the number of observations $(\mathrm{N})$, minimum, maximum, mean, Median and standard deviation of the variables used. Corporate Social Responsibility Expenditure (ECSR) has a Mean value of 91.64615, Median value of 89.60000 with a standard deviation value of 10.26187. It has a minimum and maximum value of 67.00000 and 102.0000 respectively. Average Manufacturing Capacity Utilisation (AMCU) has a Mean and median values of 74.38462 and 76.00000 respectively; with a standard deviation value of 12.80975 . It has a minimum and maximum value of 56.00000 and 99.00000 respectively. Employee's productivity rate (EMR) has a Mean and median values of 69.69231 and 68.00000 respectively; with a standard deviation value of 10.88871. It has a minimum and maximum values of 45.00000 and 87.00000 respectively. Company output rate (COR) has a Mean and median values of 68.76923 and 67.00000 respectively; with a standard deviation value of 16.27449. It has a minimum and maximum value of 45.00000 and 88.00000 respectively, with 14 as the total number of observation.

\section{Result of Regression Analysis for Financial Performance}

The estimated Simple linear regression model becomes:

$\mathrm{FPM}=10.41730+5.772911 \mathrm{ECSR}$

$\mathrm{R}^{2}=0.99 \quad$ Adjusted $\mathrm{R}^{2}=0.96$

\section{Result of Regression Analysis for Non-Financial Performance}


The estimated simple linear regression model becomes:

$\mathrm{NFPM}=9.31780+4.47681 \mathrm{ECSR}$

$\mathrm{R}^{2}=0.96 \quad$ Adjusted $\mathrm{R}^{2}=0.94$

Note: The Eview regression output result is captured in the appendix

\section{DISCUSSION}

This research work aims to examine the impact of corporate social responsibility on the performance of manufacturing firm a case study of shoes and footwear making industry. Our findings have shown that ECSR has a positive and significant impact on the Financial and non-financial Performance of Manufacturing Firm (shoes and footwear making industry). The coefficient of determination (R2) shows that about 99 percent of the variation in the dependent variable (FPM) was explained by the changes in the explanatory variable (ECSR) of the estimated model with respect to the financial performance of the manufacturing firm, while the non-financial performance, the (R2) is given as 94 percent suggesting that $94 \%$ of the total variation in the dependent variable (NFPM) was explained by the independent variable (ECSR) of the estimated model. This implies that the estimated models has a good fit. This study is in line with results of previous efforts in the field especially one by Javed, Saeed, Lodhi and Malik (2013) which suggest that there is a positive relationship between firms, financial performance, economic and legal responsibilities, ethical and discretionary responsibilities. They also conclude that CSR by corporate sector provides a healthy environment for the country and promotes a culture in which laws are abided willingly. Cheruiyot (2018) using regression analysis found that there was a positive and statistically significant relationship between CSR and financial performance of manufacturing firms. Scholtens (2018) using Ordinary least square OLS and Granger Causation techniques of analysis found that there is a significant relationship between CSR and financial performance of manufacturing firm, though components of CSR like community involvement, employee relations, diversity, environment does not have positive relationship with financial performance in respect of return and risk. A few limitations need to be acknowledged. First, out of the many manufacturing firms in the country, only the shoe and footwear making industry was selected and used for the study. Findings were limited in scope and future studies can extend to more manufacturing firms. Second, the secondary data of the study did not include all the financial and non-financial performance indicator due to data non-availability and accessibility, suggesting that further analysis of the model should be made using data from all financial and non-financial performance indicators.

\section{CONCLuSion}

A good number of previous studies showed that CSR activities impact positively and significantly on the performance of the manufacturing firms. Our findings have shown that ECSR has a positive and significant impact on the Financial and non-financial Performance of Manufacturing Firm (shoes and footwear making industry). The evidence are clearly capture in the empirical review as well as the major findings of this study. Expenditure on ECSR has enhanced the performance of the manufacturing firm over the period studied. It also has the potential to promote the performance of the manufacturing firm in Nigeria within the period under review. It therefore, implies that increased funding of the activities of Corporate Social Responsibility (CSR) will contribute to the growth, development and better performance of the shoe and footwear manufacturing firms in Nigeria.

\section{RECOMMENDATIONS}

On the basis of the above research questions, research objectives and research findings the following recommendations are proffered:

- There should be increase investment and spending on Corporate Social Responsibility to ensure that the positive and significant impact on the financial performance of shoes and footwear making industry is sustained over time.

- An improvement in Corporate Social Responsibility expenditure (ECSR) to sustain the positive and significant impact on the non-financial performance of manufacturing firms (shoes and footwear industry) is a welcome development. 


\section{REFERENCES}

[1] Afsheen S (2015) Impact of corporate social responsibility on firm's performance, City University of Science \& Information Technology Peshawar Pakistan: In proceeding for Journal of Finance and Bank Management.

[2] Al Matari EM, Al-Swidi AK, \& Fadzil FHB, (2014) The measurements of firm performance dimensions, Asian Journal of Finance \& Accounting 6 (1), 24-49

[3] Amole BB, Adebiyi SO, and Awolaja AM (2012) Corporate social responsibility and performance of selected firms in Nigeria. Resrearch Journal of Finance and Accounting , 3 (1) pp 6-17

[4] Awan AG, and Akhtar N (2014) The impact of Corporate social responsibility on Profitability of firms: a case study of fertilizer and cement Industry in Southern Punjab, Pakistan: International Journal of Development and Economic Sustainability, 2 (4) pp 70-79

[5] Babalola, Y. A. (2013). The Impact of Corporate Social Responsibility on Firms' Profitability in Nigeria. European Journal of Economics, Finance and Administrative Sciences, 45, 39-50.

[6] Benabou M. L.\& Tirole G(2017), „Beyond Dichotomy: The Curvilinear Relationship Between Social Responsibility and Financial Performance ${ }^{e e}$. Strategic Management Journal. Vol 27(11), 1101-1156.

[7] Black,S. (2009) Introduction to Public Relations. London: The Midino Press Limited.

[8] Brammer S, Pavelin S, and Porter LA (2006) Corporate Social Performance and geographical diversification. Journal of Business Research 59 (9): 1025-1034, Sept. 2006

[9] Cheruiyot, F. K. (2018). The relationship between corporate social responsibility and financial performance of companies listed at the Nairobi Stocks Exchange, Unpublished MBA Thesis, University of Nairobi.

[10] Chetty S, Naidoo R, and Seetharam Y (2015) The impact of corporate social responsibility on firms financial performance in South Africa university of the Witwatersrand- School of Economics and Business Sciences

[11] Enahoro, J. A., Akinyomi, O. J., \& Olutoye, A. 1. (2013). Corporate Social Responsibility and Financial Performance: Evidence from Nigerian Manufacturing Sector. Asian Journal of Management Research, 4(1), 153-162.

[12] Foote, J., Gaffney, N. and Evans, J. R. (2010). Corporate Social Responsibility: Implication for Performance Excellence. Total Quality Management. 21(8), 799-812.

[13] Harpreet. G (2017). The Impact of Corporate Governance on Firm Performance: A Study on Selected Insurance Companies in Ethiopia. Thesis Submitted to College of Business and Economics Jimma University pp. 1-55

[14] Idowu SO, and Papasolomou I (2007) Are the corporate social responsibility matters based on good intentions or false pretences? An empirical study of the motivations behind the issuing of CSR reports by UK companies, Corporate governance, 7 (2), 136-147

[15] Iqbal, N., Ahmad, N., Basheer, N. A., \& Nadeem, M. (2012). Impact of Corporate Social Responsibility on Financial Performance of Corporations: Evidence from Pakistan. International Journal of Learning \& Development, 2(6), 107-118.

[16] Jaenick B (2013) Analysis of how corporate social responsibility (CSR) policies creates Value Added for companies. Published MBA (Finance) Dissertation, Dublin Business School.

[17] Javed M., Saeed R., LodhiRab N., Malik Q. (2013) the Relationship between Corporate Social Responsibility and Firm Financial Performance: A Case of Pakistan. Journal of Basic and Applied. 3(11)34-45

[18] Jenkins H. (2009), A business opportunity model of corporate social responsibility for small and mediumsized enterprises. Business Ethic: A European Review 18 (1): 21-36. https://doi.org/10.1111/j.14678608.2009.01546.x

[19] Kanwal M., Khanam F., Nasreen S. and Hameed S (2018). Impact of corporate social responsibility on the firm's financial performance. IOSR Journal of Business and Management. Vol 14(5) 67-74

[20] King A, Lenox M, (2002) Exploring the locus of profitable pollution reduction. Management Science 48 (2): 289-300. https://doi.org/10.1287/mnsc.48.2.289.258

[21] Klassen RD, Whybark DC, (1999) The impact of environmental technologies on manufacturing performance. Academy of Management Journal 42 (6): 599-615. https://doi.org/10.2307/256982

[22] Kotler P and Lee N (2005) Social Marketing quarterly, journals.sagepub.com

[23] Maduenoa JH, Jorgea ML, Conesab IM, Martinez D (2015) Relationship between corporate social responsibility and competitive performance in Spanish Smes: empirical evidence from a stakeholder's 
perspective.M (2014) Impact of corporate social responsibility on the financial performance of banks in Pakistan. International Letters of Social and Humanistic Sciences, Vol.21, pp 9-19

[24] Malik MS, \& Nadeem

[25] McWilliams, A. \& Siegel, D. (2018). "Corporate social responsibility and financial performance: Correlation or misspecification?” Strategic Management Journal 21(5), 603-609.

[26] Miles MP and Munilla LS (2005) the corporate social responsibility continuum as a component of stakeholder theory. https://doi.org/10.1111/j.0045-3609.2005.00021.x, Business and Society Review, 110:4 371-387

[27] Mirfazli, E. (2018). "Corporate social responsibility (CSR) information disclosure by annual reports of public companies listed at Indonesia Stock Exchange (IDX)”, International Journal of Islamic and Middle Eastern Finance and Management 1(4), 275 - 284.

[28] Mishra S, Suar D (2010) Does corporate social responsibility influence firm performance of Indian companies? Journal of Business Ethics 95: 571-601. https://doi.org/10.1007/s10551-010-0441-1

[29] Mujahid, Mubeen and Abdullah, Arooj. (2014). Impact of Corporate Social Responsibility on Firms Financial Performance and Shareholders Wealth. European Journal of Business and Management. 6(31), 181-187.

[30] Neely A (2007) Business Performance Measurement Unifying theories and integrating practices $\left(2^{\text {nd }} \cdot\right.$ Ed $)$ NY, USA: Cambridge University Press

[31] Odetayo, T., Adeyemi, A. \& Sajuyigbe, A. (2017). Impacts of Corporate Social Responsibility on profitability of Banks: International Journal of Academic Research in Business and Social Sciences, 4(8), 252-263

[32] Okeudo GN, (2012) Effect of corporate social responsibiblity on the society (using Shell Petroleum Development Company as a case study. British Journal of Science, 3 (1), pp156-163

[33] Okwemba EM, Chitiavi MS, Egessa R, Douglas M, Musiega MG (2014) Effect of corporate social responsibility on organization performance: banking industry Kenya, Kakamega country. International Journal of Business and Management Invention 3 (4): 37-51

[34] Olaroyeke O, and Nasieku. (2015), “Appraisal of the Practice of Social Responsibility byBusiness Organisations in Nigeria" Covenant University, Ota, Nigeria

[35] Olowokudejo F, Aduloju SA, Oke SA, (2001) corporate social responsibility and organizational effectiveness of insurance companies in Nigeria. The Journal of Risk Finance 12 (3): 156-167. https://doi.org/10.1108/15265941111136914

[36] Olusanya SO, Awotungase SA, Oyebo AO, (2012) corporate social responsibility and effectiveness of small and medium enterprises (Smes) in Nigeria. Journal of Business and Management 5 (1): 40-47

[37] Orlitzky, M., Schmidt, F. L. \& Rynes, S. L. (2013).Corporate Social and Financial Performance: A MetaAnalysis", Organization Studies 24(3), 403-441.

[38] Ortlitzki, M., Schmidt, F. ., \& Rynes, S. (2003). Corporate Social and Financial Performance: Ameta Analysis. Organization Studies, 46(9), 1437 -1443.

[39] Onabanjo O. (2015), "Appraisal of the Practice of Social Responsibility by Business Organisations in Nigeria. Retrieved - December 18, 2013 from http://www.socialresponsibility.bus/companies/cull.pdf.

[40] Osisioma H, Nzewi H and Nwoye P (2015) Corporate social responsibility and performance of selected firms in Nigeria. IMPACT: International Journal of Research in Business Management (IMPACT: IJRBM), 3(3) pp 57-68

[41] Post C, Rahman N, Rubow E, (2011) Green governance: Boards of director' composition and environmental corporate social responsibility. Business Society 50 (1): 189-223. https://doi.org/10.1177 /0007650310394642

[42] Scholtens, B. (2018). A Note on the interaction between corporate social responsibility and financial performance. Ecological Economics. 68(1-2), 46-55 Corporate Social Responsibility. Economica, 77,

[43] Servaes H, and Tamayo A (2012) The impact of corporate social responsibility on firm value: the role of customer Awareness. Forthcoming Management Science Electronic copy available at: http://ssrn.com/abstract 2116265

[44] Suroca J, Tribo JA, Waddock S (2010) Corporate responsibility and financial performance: the role of intangible resources. Strategic Management Journal 31: 463-490. https://doi.org/10.1002/smj.820

[45] Stancu A, Grigore GF and Rosca MI (2011) The impact of corporate social responsibility on employees. International conference on Information and finance, IPEDR Vol.21. 
Impact of Corporate Social Responsibility on the Performance of Manufacturing Firms in Nigeria.

[46] Teimouri ME, Jamehshooran BG, Heydari AR (2001) Relationship between CSR SCA (case study body shop). Interdisciplinary Journal of Contemporary Research in Business 3(2): 556-576

[47] Torugsa NA, O’Donohue W, Hecker R (2012) Capabilities, proactive CSR and financial performance in smes: empirical evidence from an Australian manufacturing industry sector. Journal Business Ethics 109: 483-500. https://doi.org/10.1007/s10551-011-1141-1 Approaches. Academy of Management Journal, Vol. 20, No. 3, pp. $571-610$.

[48] Uwaloma, O. M. \& Fagbemi, T. O. (2018). "Corporate Social Responsibility and Financial Performance in Developing Economies: The Nigerian Experience". The 2018 New Orleans international Academic Conference.UK Evidence from Disaggregate Measures, Financial Management 35, 97-116.

\section{APPENDIX 1}

Table4.1. Financial performance/Corporate Social Responsibility indicators

\begin{tabular}{|l|l|l|l|l|}
\hline YEAR & ECSR N(MILLION) & PAT N(MILLION) & ROI N(MILLION) & AFV N(MILLION) \\
\hline 2005 & 15.6 & 13.5 & 45.3 & 78.6 \\
\hline 2006 & 17.5 & 14.5 & 65.3 & 79.2 \\
\hline 2007 & 18.3 & 16.5 & 78.7 & 97.3 \\
\hline 2008 & 17.3 & 18.3 & 89.4 & 99.8 \\
\hline 2009 & 18.2 & 17.6 & 89.3 & 89.5 \\
\hline 2010 & 19.2 & 19.2 & 98.3 & 100.6 \\
\hline 2011 & 18.2 & 20.2 & 101.3 & 102.5 \\
\hline 2012 & 19.2 & 21.3 & 102.3 & 104.2 \\
\hline 2013 & 19.3 & 22.1 & 103.2 & 106.8 \\
\hline 2014 & 19.2 & 21.3 & 105 & 108.7 \\
\hline 2015 & 16.2 & 23.1 & 108 & 120 \\
\hline 2016 & 20.1 & 24.5 & 109.6 & 110.7 \\
\hline 2017 & 22.2 & 67.3 & 110.4 & 111.3 \\
\hline 2018 & 21.2 & 3.4 & & 112.8 \\
\hline
\end{tabular}

Source: Central Bank of Nigeria, 2019

\section{Manufacturers Association of Nigeria (MAN) Report, 2019}

Where:

ECSR $=$ Corporate Social Responsibility Expenditure, PAT $=$ Profit after tax, AFV= Asset Financial Value, ROI= Return on Investment

\section{APPENDIX 11}

Table4.2. Non Financial performance/Corporate Social Responsibility indicators

\begin{tabular}{|l|l|l|l|l|}
\hline YEAR & ECSR N(MILLION) & AMCU (\%) & EMR (\%) & COR (\%) \\
\hline 2005 & 89.8 & 78.7 & 56 & 56 \\
\hline 2006 & 87.6 & 89.8 & 78 & 67 \\
\hline 2007 & 67.6 & 67.8 & 67 & 87 \\
\hline 2008 & 79.9 & 56.6 & 45 & 76 \\
\hline 2009 & 89.6 & 76.7 & 67 & 88 \\
\hline 2010 & 99.7 & 67.6 & 87 & 45 \\
\hline 2011 & 101.3 & 56.4 & 69 & 56 \\
\hline 2012 & 87.4 & 67.4 & 78 & 65 \\
\hline 2013 & 99.4 & 78.0 & 68 & 78 \\
\hline 2014 & 98.3 & 78.7 & 67 & 87 \\
\hline 2015 & 89.5 & 99.5 & 67 & 56 \\
\hline 2016 & 101.3 & 89 & 79 & 88 \\
\hline 2017 & 102 & 67 & 78 & 45 \\
\hline 2018 & 103 & 89 & 82 & 87 \\
\hline
\end{tabular}

Source: Central Bank of Nigeria, 2019

\section{Manufacturers Association of Nigeria (MAN) Report, 2019}

Where:

$\mathrm{ECSR}=$ Corporate Social Responsibility Expenditure, AMCU= Average Manufacturing Capacity Utilisation, $\mathrm{EMR}=$ Employee's Productivity rate, $\mathrm{COR}=$ Company's output rate 


\section{APPENDIX 111}

Financial Performance: The regression output using E-Views is given below as:

\begin{tabular}{|c|c|c|c|c|}
\hline \multicolumn{5}{|c|}{ Dependent Variable: FPM } \\
\hline \multicolumn{5}{|c|}{ Method: Least Squares } \\
\hline \multicolumn{5}{|c|}{ Date: 05/05/20 Time: 06:53 } \\
\hline \multicolumn{5}{|c|}{ Sample: $2005-2018$} \\
\hline \multicolumn{5}{|c|}{ Included observations: 14} \\
\hline Variable & Coefficient & Std. Error & t-Statistic & Prob. \\
\hline $\mathrm{C}$ & 10.41730 & 2.532011 & 4.114239 & 0.0005 \\
\hline ECSR & 5.772911 & 1.400823 & 4.121085 & 0.0000 \\
\hline R-squared & 0.988377 & \multicolumn{2}{|c|}{ Mean dependent var } & 4505090. \\
\hline Adjusted R-squared & 0.955920 & \multicolumn{2}{|c|}{ S.D. dependent var } & 6801248. \\
\hline S.E. of regression & 1255127. & \multicolumn{2}{|c|}{ Akaike info criterion } & 31.02107 \\
\hline Sum squared resid & $4.10 \mathrm{E}+13$ & \multicolumn{2}{|c|}{ Schwarz criterion } & 31.16251 \\
\hline Log likelihood & -446.8055 & \multicolumn{2}{|c|}{ Hannan-Quinn criter. } & 31.06537 \\
\hline F-statistic & 255.1982 & \multicolumn{2}{|c|}{ Durbin-Watson stat } & 1.666554 \\
\hline Prob(F-statistic) & 0.000000 & & & \\
\hline
\end{tabular}

APPENDIX IV

Non-financial performance: The regression output using E-Views is given below as:

\begin{tabular}{|l|l|l|l|}
\hline Dependent Variable: FPM & & \\
\hline Method: Least Squares & & \\
\hline Date: 05/05/20 Time: 06:53 & & \\
\hline Sample: 2005 -2018 & & \\
\hline Included observations: 14 & Std. Error & t-Statistic & \\
\hline Variable & Coefficient & Prob. \\
\hline C & 9.31780 & 1.432201 & 4.121085 \\
\hline ECSR & 4.476813 & 1.400823 & 0.0025 \\
\hline R-squared & 0.964357 & Mean dependent var & 0.0030 \\
\hline Adjusted R-squared & 0.943720 & S.D. dependent var & 5544090. \\
\hline S.E. of regression & 1255127. & Akaike info criterion & 7803348. \\
\hline Sum squared resid & $4.10 \mathrm{E}+13$ & Schwarz criterion & 41.02227 \\
\hline Log likelihood & -446.8055 & Hannan-Quinn criter. & 41.16251 \\
\hline F-statistic & 265.1982 & Durbin-Watson stat & 33.06537 \\
\hline Prob(F-statistic) & 0.000000 & & 1.766554 \\
\hline
\end{tabular}

Source: Eview Output, May 2020

\section{AUTHOR'S BIOGRAPHY}

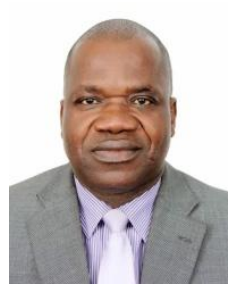

John Azumah, is an student of the Nile University of Nigeria.

Citation: John Azumah "Impact of Corporate Social Responsibility on the Performance of Manufacturing Firms in Nigeria." International Journal of Managerial Studies and Research (IJMSR), vol 8, no. 7, 2020, pp. 01-15. doi: http:// dx.doi.org/10.20431/2349-0349.0807001.

Copyright: (C) 2020 Authors. This is an open-access article distributed under the terms of the Creative Commons Attribution License, which permits unrestricted use, distribution, and reproduction in any medium, provided the original author and source are credited. 